\title{
Synergistic effect of combined IFN-alpha2b and IFN-gamma treatment for periocular basal cell carcinoma
}

\section{Tratamiento del carcinoma basocelular periocular con una combinación sinérgica de interferones Alpha-2b y gamma}

\author{
Yairan Negrin-Caceres ${ }^{1 *}$, Ailyn C. Cabrera-Romero ${ }^{1}$, Ledisleydy Cárdenas-Monzón ${ }^{1}$, Arletis Ferrer-Pérez ${ }^{2}$ \\ and Norma E. Batista-Hernández ${ }^{3}$ \\ ${ }^{1}$ Centro Oftalmológico, Hospital Arnaldo Milián Castro; ${ }^{2}$ Hospital Arnaldo Milián Castro; ${ }^{3}$ Unidad de Investigaciones Biomédicas, Universidad de \\ Ciencias Médicas. Villa Clara, Cuba
}

\begin{abstract}
Purpose: To assess the results of the application of perilesional HerberPAG ${ }^{\otimes}$ on periocular basal cell carcinoma. Methods: An experimental investigation was carried out on a group of 7 patients who received the same treatment regimen with HeberPAG ${ }^{\oplus} 10.5 \times 10^{6}$ IU 3 times a week for 3 consecutive weeks. Demographic variables were evaluated as well as duration, initial lesion size, clinical subtype, histological subtype, clinical response, objective response and adverse events. Results: The average time of lesion duration was $7.0 \pm 1.6$ months, with a large diameter mean of $17.4 \pm 2.3 \mathrm{~mm}$. The clinical nodular-ulcerative subtype was present on $42.9 \%$ of the subjects and the solid and superficial histological subtypes were present with an equal proportion of $42.9 \%$. Conclusions: The use of HerberPAG ${ }^{\oplus}$ was an effective and safe alternative to conservative treatment in subjects with periocular basal cell carcinoma when other therapies are not available.
\end{abstract}

Key words: Basal cell carcinoma. Interferons. HeberPAG ${ }^{\circledR}$.

\section{Resumen}

Objetivo: Evaluar los resultados de la aplicación del HeberPAG ${ }^{\circledR}$ perilesional, en carcinoma basocelular periocular. Método: Se realizó una investigación experimental, en un grupo de siete pacientes a los que se les aplicó un mismo esquema de tratamiento con HeberPAG ${ }^{\circledR} 10.5$ × 106 UI perilesional 3 veces a la semana durante 3 semanas consecutivas. Se consideraron variables demográficas, así como tiempo de evolución, tamaño inicial de la lesión, subtipo clínico, subtipo histológico, respuesta clínica, respuesta objetiva (RO) y eventos adversos. Resultados: El tiempo promedio de evolución de la lesión fue de $7.0 \pm$ 1.6 meses, con un diámetro mayor medio de $17.4 \pm 2.3 \mathrm{~mm}$. El subtipo clínico nódulo ulcerativo se presentó en el $42.9 \%$ de los casos y los subtipos histológicos sólido y superficial se presentaron con igual proporción, en un 42.9\%. El diámetro mayor de la lesión mostró un comportamiento decreciente en función del tiempo, y a las 16 semanas se alcanzó una respuesta clínica completa y objetiva en el $85.7 \%$ de los casos. Todos los pacientes presentaron eventos adversos, que se resolvieron con medicación oral sin abandonar el tratamiento. La totalidad de ellos ofrecieron un alto grado de satisfacción con el tratamiento. Conclusiones: El empleo del HeberPAG ${ }^{\circledR}$ resultó ser efectivo, por lo que se podría considerar como una alternativa útil y segura como tratamiento conservador en pacientes con carcinoma basocelular periocular cuando otras terapias no son posibles.

Palabras clave: Carcinoma basocelular. Interferones. HeberPAG ${ }^{\oplus}$

Correspondence:

*Yairan Negrin-Caceres

Av. Nuevo Hospital e/Doble Vía y Circunvalación

Date of reception: 07-06-2017

Date of acceptance: 01-03-2018

DOI: 10.24875/RMOE.M18000014
Available online: 14-05-2018 Rev Mex Oftalmol (Eng).2018;92(3):115-121 www.rmo.com.mx E-mail: ynegrinc@gmail.com 2604-1731/@ 2018 Sociedad Mexicana de Oftalmología. Published by Permanyer México SA de CV. This is an Open Access article under the CC BY-NC-ND license (http://creativecommons.org/licenses/by-nc-nd/4.0/). 


\section{Introduction}

Basal cell carcinoma (BCC) is a malignant neoplasm derived from non-keratinized cells that originates from the basal layer of the epidermis. It is the most common cancer type in humans ${ }^{1,2}$. There are 2.8 million BCC cases diagnosed each year in the US and 700,000 new cases in Europe. Skin cancer in the US population exceeds the statistics of other types of cancer; it is estimated that 1 in 5 Americans will develop skin cancer during their lives ${ }^{3,4}$. It represents between 80 to $90 \%$ of all malignant skin conditions ${ }^{5}$. In addition, it is the most frequent periocular malignant tumor $(80-95 \%)^{6,7}$. Its etiopathogenesis is related to age, genetic, viral and environmental factors (ultraviolet radiation) ${ }^{3}$. In the last decade, an increase in its incidence and a tendency to appear at younger ages has been detected ${ }^{5}$.

Initially it presents as a slow-growth small tumor, with the appearance of an ulcerated lesion, with telangiectasias and rounded margins; however, the signs may vary according to the clinical subtype. The local destruction it causes can be significant in relevant structures such as the eyelids, and can generate deformities or loss of function of the affected organ ${ }^{7,8}$.

Selecting the appropriate treatment will depend in each case on the size of the lesion, location, BCC subtype, general condition, age and aesthetic needs of the patient. Surgery continues to be the first therapeutic option. Traditionally, BCC has been completely removed with 3 to $4 \mathrm{~mm}$ of surgical margin combined with primary reconstruction, and excellent results have been obtained $^{9}$. Alternatives such as radiotherapy, cryotherapy, laser ablation, chemotherapy and immunotherapy have been described as useful variants in inoperable cases or extensive lesions. Topical treatment with imiquimod may be an alternative to surgery, but long-term results are not as successful as other modalities ${ }^{10}$. Photodynamic therapy is not generally recommended for BCC management due to low success rates in head and neck ${ }^{11-13}$.

Conservative treatment of BCC is important in the periocular region, because when surgery is performed respecting the oncological margin at this level, it may involve the removal of large areas of the visual apparatus. The reconstruction of the affected area can cause serious aesthetic and functional alterations. In addition, for aesthetic reasons, there is a tendency in facial surgery to eliminate as little tissue as possible and consequently, tumor margins are not completely resected. This significantly increases the risk of recurrence ${ }^{9,14,15}$. Immunotherapy is a valuable tool in the conservative management of $\mathrm{BCC}^{16}$. Interferon (IFN) intralesional injections were reported as effective for the treatment of BCC in a preliminary study in 1986. Other studies agree that the use of IFN in the treatment of BCC and squamous cell carcinoma (SCC) has shown a wide range of response (60$100 \%$ ), with a recurrence rate of up to $17 \%{ }^{17}$.

Although the literature on this topic is not comprehensive, encouraging results have already been published regarding the administration of the synergistic combination of IFN alpha-2b and interferon gamma (HeberPAG ${ }^{\circledR}$, Heber Biotec SA, Havana, Cuba). It was registered in 2008 by the Center for the State Control of the Quality of Medicines [CEDMED], the regulatory authority for medicines in $\mathrm{Cuba}^{17}$, and is indicated in the treatment of all BCC subtypes by intratumoral and/ or perilesional injection in BCC skin lesions, inducing total regression of the tumors ${ }^{18-20}$. This alternative enhances the pharmacokinetics of the drug by the combination of two active ingredients that can act synergistically. In this way, the same advantages are obtained with a new distribution mechanism that includes an increase and prolongation of the pharmacological activity without additional toxicity, a decrease in the frequency of injections, together with a greater compliance and quality of life of the patient ${ }^{21}$.

The objective of the authors of this study is to evaluate the results of the application of perilesional HeberPAG ${ }^{\circledR}$ in periocular $\mathrm{BCC}$ in a series of treated patients.

\section{Methodology}

An experimental study (prospective phase IV clinical trial) was conducted in patients with a diagnosis of periocular BCC, attended in the oculoplastic consultation at the Hospital Universitario Arnaldo Milián Castro de Villa Clara, Cuba, in the period from February 2014 to February 2015.

We included 7 patients of both sexes, over 18 years of age, with a diagnosis of any stage and/or clinical subtype of periocular BCC, with a lesion greater than $1 \mathrm{~cm}$ and in which surgical treatment was not recommended, as well as lesions with incomplete resection by previous surgical treatment or relapsing. Exclusion criteria were pregnant women, patients who were receiving onco-specific treatments and patients with hypersensitivity to IFN at the time of inclusion.

A positive diagnosis was established by the clinical characteristics of the lesion, histological and dermoscopic results. Incisional biopsy was performed using the $4 \mathrm{~mm}$ punch technique, with fixation of the tissue in a 
$5 \%$ formalin solution and proceeding to its inclusion in paraffin to observe the sections under a conventional light microscope. A specialist in Dermatology performed dermoscopy to establish the presence or absence of signs suggestive of tumor. Both tests were performed at the beginning and 16 weeks after treatment. All the patients in the series were treated with the same treatment scheme, using a stabilized pharmaceutical formulation containing a synergistic combination of IFN-alpha2b and IFN-gamma, sodium hydrogen phosphate, dextran 40, sodium chloride, and human albumin (HeberPAG ${ }^{\circledR}, \mathrm{He}-$ ber Biotec SA, Havana, Cuba) at a dose of $10.5 \mathrm{x}$ $10^{6} \mathrm{IU} / 1 \mathrm{ml}$, by perilesional infiltration 3 times a week for 3 consecutive weeks. All the treatments were administered on an outpatient basis and reevaluated in consultation at 4, 8, 12 and 16 weeks after the treatment was initiated, where the size of the lesion, clinical changes and adverse reactions were recorded.

Demographic variables were considered, as well as duration, initial size of the lesion, clinical subtype, histological subtype, clinical response, OR, and adverse events.

The initial size of the lesion was measured before treatment using a millimeter ruler; the histological subtype was classified according to the anatomopathological report. The clinical response was determined according to the characteristics of the lesion 16 weeks after starting the treatment. Considering this criterion, the following categories were obtained:

- Complete response (CR): total disappearance of the lesion.

- Partial response (PR): reduction of at least $30 \%$ of the sum of the largest diameters, taking as a reference the sum of the baseline largest diameters.

- Stable response (SR): not enough reduction to qualify as partial response.

- OR was expressed by the sum of $\mathrm{CR}+\mathrm{PR}$.

Hematological and biochemical determinations were made (hemoglobin, hematocrit, leukocyte and platelet count, transaminase, creatinine, urea) before and after treatment.

The long-term follow-up continued quarterly during the first year, on a biannual basis during the second and third year, and annually from the fourth to the tenth year.

The information of each patient was registered in a data collection notebook and processed using the statistical package SPSS 20.0. The results were presented in tables and graphs. Statistical techniques were applied according to the types of variables. Bayesian confidence intervals were estimated for the proportions of clinical response, with a $95 \%$ confidence. The ethical principles contained in the declaration of Helsinki for human experimentation were fulfilled and written informed consent of each patient was obtained. This study was carried out with the approval of the ethics committee of the institution. The clinical trial is registered in the Cuban Public Registry of Clinical Trials.

\section{Results}

In the period described, a total of 7 patients who received the treatment were evaluated. They had a mean age of 75 years (Table 1 ).

The mean time of tumor duration was 7 months and its largest diameter had an average value of $17.4 \mathrm{~mm}$. The clinical subtype of ulcerative nodule predominated in $42.9 \%$ of the cases, and the rest of the subtypes presented in the same proportion, accounting $14.3 \%$ for each case. From a histological point of view, the superficial and solid subtypes affected 3 patients, respectively, and only 1 presented an infiltrative subtype (Table 2).

In our series, it was observed that in general there was a decreasing, regular and sustained behavior of the large diameter of the lesion as a function of time (Fig. 1). In $85.7 \%$ of the cases, CR was obtained; only one patient presented a stable response, representing $14.3 \%$. These values showed the same behavior in the case of the histological and dermoscopic response (Table 3).

All patients evaluated had adverse events related to the administration of the medication. The most frequent was perilesional erythema, which occurred in $100 \%$ of the cases, and fever, in $71.4 \%$ (Table 4).

\section{Discussion}

Periocular BCC continues to lead the list of ocular tumors worldwide ${ }^{9,22}$. Its management depends on factors related to the patient and the characteristics of the tumor. Surgical resection and reconstruction continues to be the main standard treatment; however, in some conditions it becomes an option to evaluate. Reconstruction of the periocular region may cause eyelid retraction, ectropion or cicatricial entropion, ptosis, dry eye, tumor recurrence, trichiasis, infections, graft rejection, unsightly scars, hyper or hypopigmentation ${ }^{5,23}$. Currently, there are authors who show increasing interest in the use of immunotherapies as a non-surgical option in the treatment of non-melanoma skin cancer. As a starting point, results of the application of synergistic combinations of IFN, which offers invaluable advantages, begin to be registered. 
Table 1. Demographic characteristics of the population

\begin{tabular}{|c|c|}
\hline $\begin{array}{l}\text { Age } \\
\text { Mean } \pm S D \\
\text { Min/Max }\end{array}$ & $\begin{array}{c}74.7 \pm 11.9 \\
54 / 89\end{array}$ \\
\hline $\begin{array}{l}\text { Sex }(N . \% \%) \\
\text { Male } \\
\text { Female }\end{array}$ & $\begin{array}{l}3 / 42.9 \\
4 / 57.1\end{array}$ \\
\hline $\begin{array}{l}\text { Skin type according to Fitzpatrick scale (N.\%\%) } \\
\text { Type II } \\
\text { Type III }\end{array}$ & $\begin{array}{l}5 / 71.4 \\
2 / 28.6\end{array}$ \\
\hline
\end{tabular}

Table 2. Initial evaluation of the lesion

$\begin{array}{lc}\text { Duration (months) } & 7.0 \pm 1.6 \\ \text { Mean } \pm \text { SD } & 5 \\ \text { Minimum } & 9 \\ \text { Maximum } & \\ \text { Large diameter (mm) } & 17.4 \pm 2.3 \\ \text { Mean } \pm \text { SD } & 15 \\ \text { Minimum } & 23 \\ \text { Maximum } & \\ \text { Clinical subtype (N. } \% \%) & 1 / 14.3 \\ \text { Nodular } & 1 / 14.3 \\ \text { Ulcerative } & 3 / 42.9 \\ \text { Ulcerative nodule } & 1 / 14.3 \\ \text { Pigmented } & 1 / 14.3 \\ \text { Flat cicatricial } & \\ \text { Histological subtype (N. } \% \%) & 1 / 14.3 \\ \text { Infiltrative } & 3 / 42.9 \\ \text { Superficial } & 3 / 42.9 \\ \text { Solid } & \end{array}$

Table 3. Final evaluation of the lesion

\begin{tabular}{l|c|}
$\begin{array}{l}\text { Clinical response }\left[\mathrm{N} .{ }^{\circ}(\%)\right] \\
\text { Complete } \\
\text { Partial } \\
\text { Stable }\end{array}$ & $6(85.7)$ \\
0 \\
$\begin{array}{l}\text { Histologic response }\left[\mathrm{N} .{ }^{\circ}(\%)\right] \\
\text { Yes } \\
\text { No }\end{array}$ & $1(14.3)$ \\
\hline $\begin{array}{l}\text { Dermoscopic response }\left[\mathrm{N} .{ }^{\circ}(\%)\right] \\
\text { Yes }\end{array}$ & $6(85.7)$ \\
\hline No & $1(14.3)$ \\
\hline $\begin{array}{l}\text { Objective response }\left[\mathrm{N} .{ }^{\circ}(\%)\right] \\
\text { Complete + partial }\end{array}$ & $6(85.7)$ \\
\hline
\end{tabular}

Table 4. Adverse events

\begin{tabular}{|l|c|c|}
\hline Adverse event & Frequency & $(\%)$ \\
\hline Perilesional erythema & 7 & 100.0 \\
\hline Fever & 5 & 71.4 \\
Chills & 4 & 57.1 \\
Asthenia & 4 & 57.1 \\
Anorexia & 4 & 57.1 \\
Nausea & 1 & 14.3 \\
Vomiting & 1 & 14.3 \\
Muscle aches & 1 & 14.3 \\
\hline
\end{tabular}

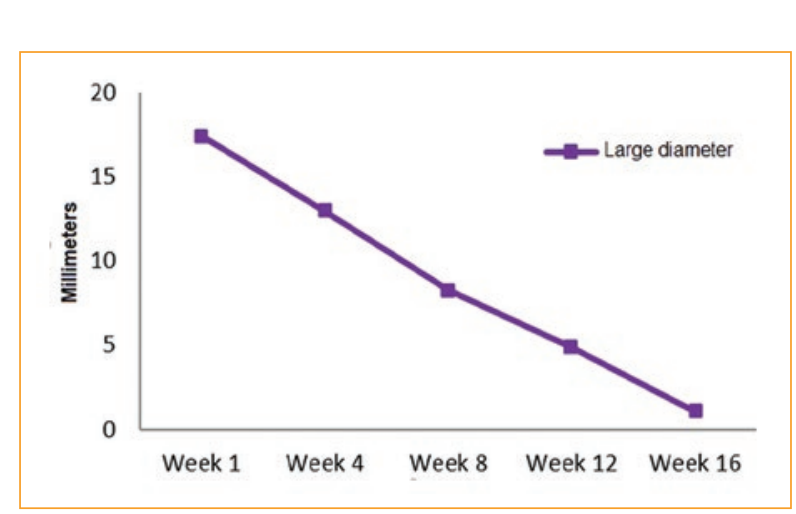

Figure 1. Variation of the large diameter mean.

In this study, the group of patients treated were people who were in average in the seventh decade of life. Some articles indicate that oncoproliferative processes are more frequent in advanced ages, although recently it has been described that there is an increasing tendency for these entities to appear more frequently in young women ${ }^{8,24,25}$, possibly associated with excessive skin tanning and sun bathing ${ }^{26-29}$.

Most patients presented skin phototype type II, according to the international Fitzpatrick classification, which coincides with the literature, where white skin is described as a risk factor for the development of $\mathrm{BCC}^{5,26}$, mainly with the cutaneous phenotype I, with freckles, red or blond hair, and light eyes. The history of exposure to solar radiation, particularly ultraviolet radiation, in inverse correlation to the decrease in skin pigmentation, is generally considered the main risk factor for $\mathrm{BC}^{26,30}$.

In the group studied, there were no significant differences in terms of sex, although there are authors who suggest that its presentation is more frequent in men, ${ }^{8,26}$ with an approximate ratio of 1.5-2:124.

Mean diameter of the diagnosed lesions was $17.4 \mathrm{~mm}$. It is suggested that metastasis due to BCC is extremely rare $^{17,31}$; however, there is a risk of $0.55 \%$ after years of diagnosis without treatment. Metastasis involves regional lymph nodes, bones, liver and lung, mainly when the lesion has a diameter $>2 \mathrm{~cm}$, the resection is incomplete and has perineural and/or perivascular compromise ${ }^{17,26}$.

In this study a patient was diagnosed with periocular BCC with a diameter of $2.3 \mathrm{~cm}$; however, it had an excellent response to treatment with a surprising clinical and aesthetic evolution.

The treatment with the synergistic combination of IFN achieved an OR in $85.7 \%$ of the cases (CR $85.7 \%+$ $\mathrm{PR} 0$ ); in each case, CR coincided with the histological and dermoscopic results. Only one patient presented $\mathrm{SR}$, since his lesion modified but without reaching a 


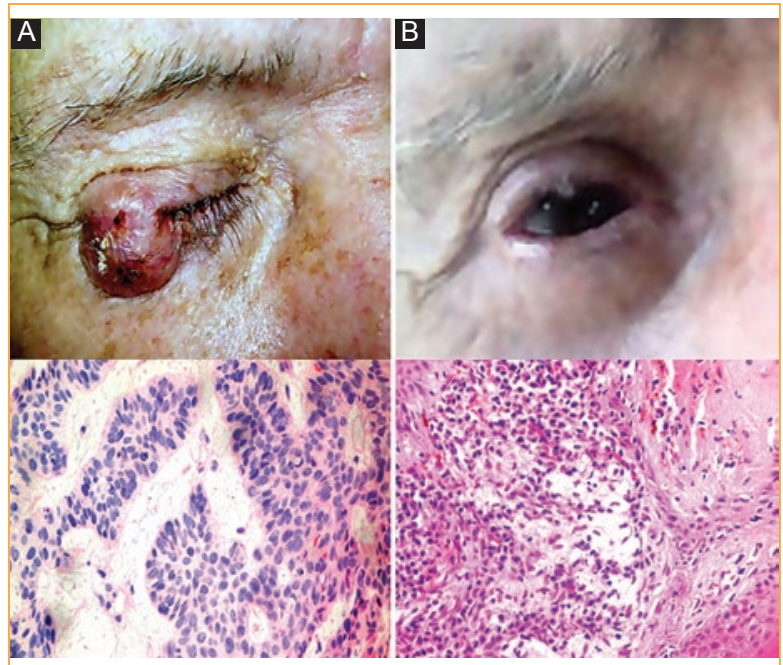

Figure 2. A 86-year-old patient with a $2.3 \mathrm{~cm}$ diameter BCC located in the outer canthus and in the outer third of the upper and lower eyelids. Complete response was obtained. In this case, a surgical treatment that covers the margins of the recommended surgical resection may not offer the aesthetic results obtained. A: before treatment; B: after treatment.

$30 \%$ reduction, and he underwent surgery with a wide-margin excision and aesthetic reconstruction. The OR obtained in these cases was similar to that described by García Vega, et al. ${ }^{19}$ in a recent study on the application of $\mathrm{HeberPAG}^{\circledR}$ in the periocular region using the same dose of this study.

Figures 2, 3 and 4 show examples of $\mathrm{CR}$ and figure 5 shows a case of SR. In all of them, clinical-histological correlation of the lesion with hematoxylin and eosin staining is represented.

Only the patient represented in figure 5 had SR to treatment. The authors propose that, despite the excellent results that HeberPAG ${ }^{\circledR}$ has shown, there is the possibility of not achieving a clinical response, mainly when the characteristics of the tumor prevent the correct diffusion of the drug. Anasagasti, et al. ${ }^{20}$ have recorded impressive and very stimulating results using a combination of HeberPAG ${ }^{\circledR}$ with chemotherapy and/ or radiotherapy, but this was not the objective of our work and it was not due to ethical reasons.

Recently, the use of vismodegib was approved for the treatment of advanced BCC, which acts through a mechanism of inhibition of the Hedgehog pathway 8,32 . García Vega compared the effectiveness of vismodegib vs. HeberPAG ${ }^{\circledR}$ in the treatment of non-melanoma skin cancer, and found an evident greater clinical effect with HeberPAG $^{\circledR}$, with a longer response duration ${ }^{8,17,33,34}$.

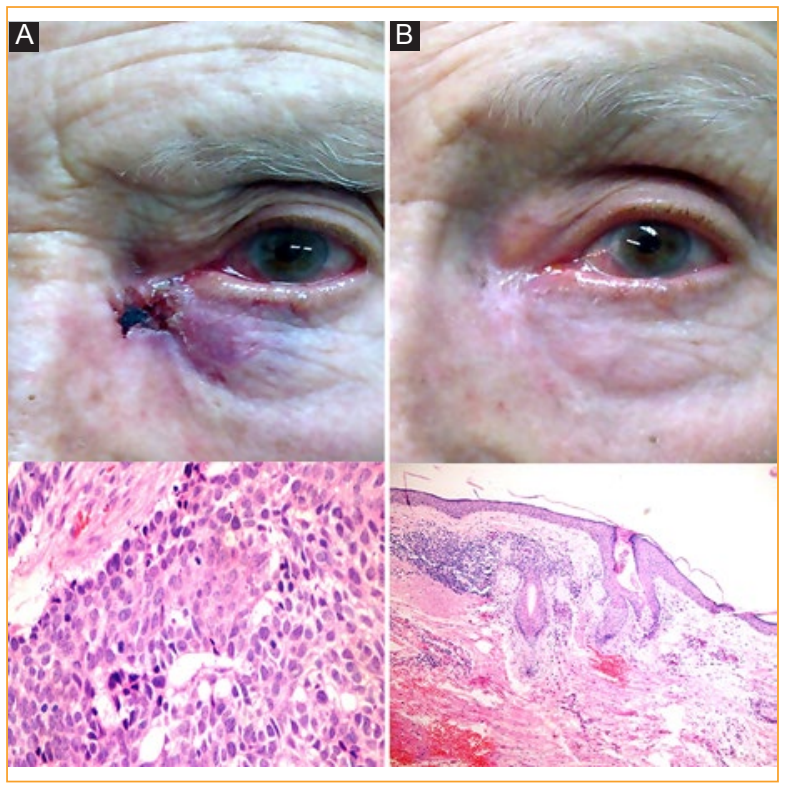

Figure 3. A 83-year-old patient diagnosed with BCC, with a deep and wide lesion located in the left lower eyelid, adjacent to the excretory lacrimal duct. In this case, it would be very difficult to achieve a total resection of the tumor concerning the depth; also, mutilation of the lacrimal ducts would be inevitable. Complete response was obtained with satisfactory aesthetic result and correct functioning of the lacrimal excretory pathway. A: before treatment; B: after treatment.

The possible mechanisms involved in the clinical effects observed with the IFN combination could be the following: intralesional IFN induces apoptosis of BCC cells through the CD95 ligand-receptor interaction, a mechanism that may be reinforced by IFN through the increase of the CD95 receptor. IFN, by stimulating the expression of the IFN-receptor, could contribute to reverse the observed low levels of this membrane receptor in BCC cells. Additionally, it has been shown that in the presence of IFN-, intracellular IFN signaling is stronger. Both IFNs have anti-angiogenic activity and significantly suppress the expression of the CXCR-4 gene, which in turn can decrease the vascularity surrounding non-melanoma skin cancer and affect the migration induced by SDF-1 and also the migration of CXCR-4 positive cells, as has been demonstrated in squamous cell carcinomas of the head and neck for IFN-. All these properties of IFN, among others, probably contribute to increase the antitumor activity of this new formulation of IFN ${ }^{20,35}$.

The most frequent adverse events with the treatment were perilesional erythema (100\%), fever $(71.4 \%)$, asthenia, anorexia, chills (57.1\%) and, less frequently, 


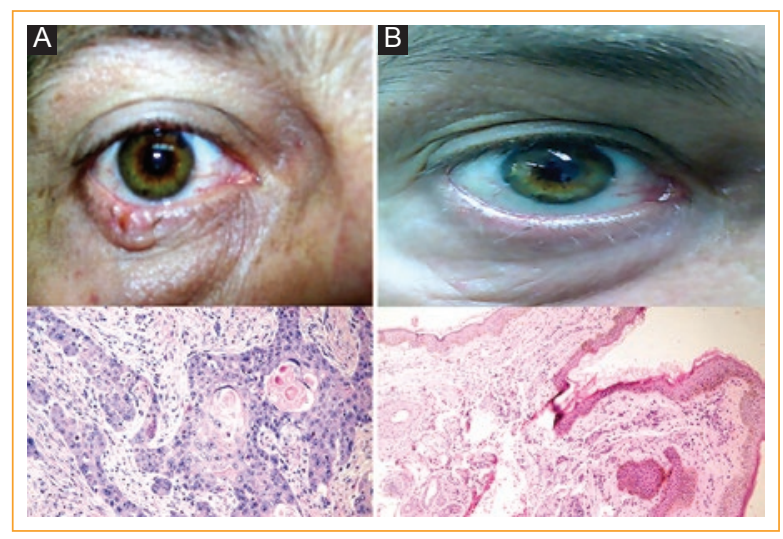

Figure 4. Patient with BCC previously treated with surgery, with a lesion that occupies the middle third of the lower eyelid and extends to the free eyelid margin. Complete remission was obtained. A: before treatment; B: after treatment.

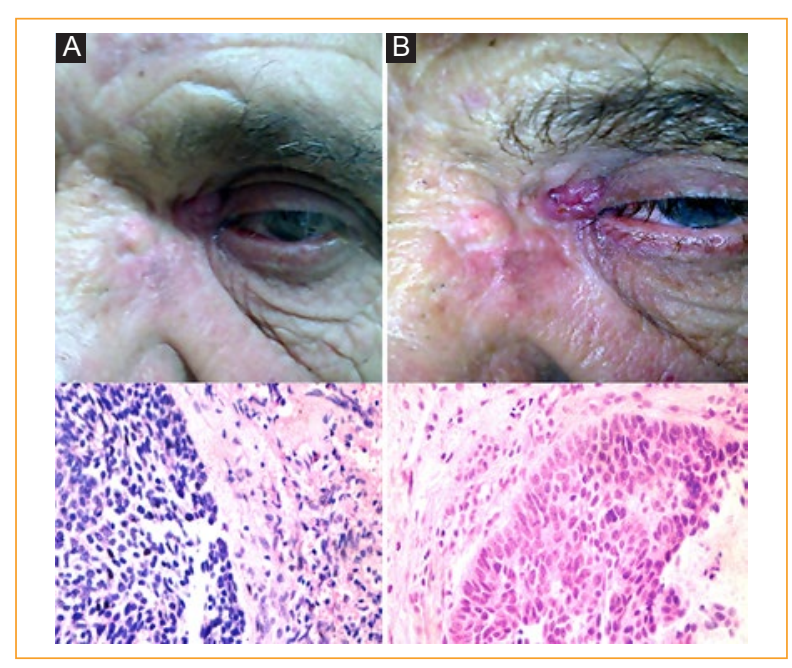

Figure 5. Patient with BCC located in the left internal canthus, without prior treatment. SR was obtained at week 16; surgery + reconstruction was performed. The margins of the surgical resection were free of tumor. A: before treatment; B: after treatment.

nausea, vomiting and muscle aches. There were no changes in hematological or biochemical tests. These results coincide with other studies ${ }^{17,20}$. All the reported events were mild in intensity and responded well to symptomatic treatment, without having to discontinue the administration of HeberPAG ${ }^{\circledR}$. This indicates that the synergistic administration of IFN has a safety profile similar to other marketed pharmaceutical presentations of IFN, which, together with the clinical effects of the combination of IFN, suggest that its use is safe and possible in similar therapeutic designs and prolonged treatment schemes, with the purpose of offering these patients an effective and safe therapeutic option ${ }^{20}$.

The adverse effects reported in patients with vismodegib exceeded $30 \%$ of the cases, and included muscle spasms, alopecia, taste alterations, weight loss and fatigue, and were serious in $25 \%$ of them ${ }^{33}$. However, HeberPAG ${ }^{\circledR}$ is considered a safe drug, with transient adverse reactions, such as catarrhal symptoms, which can be managed with pre-medication without having to discontinue the administration of IFN ${ }^{17}$. In a recent investigation, García Vega, et al. ${ }^{36}$ conducted a compassionate study in a small series of patients with high-grade inoperable brain gliomas, and they noted that the combination of IFN showed signs of clinical improvement and quality of life of these patients, with an acceptable safety profile.

Mohs micrographic surgery continues to be the standard option for the cure of all BCCs located on the face, with an approximate recurrence rate of $6.5 \%$ at 5 years ${ }^{37}$. However, due to time and cost limitations, it is reserved for cases with high risk of recurrence ${ }^{24,38,39}$. Therefore, treatment with HeberPAG ${ }^{\circledR}$ is useful before surgical treatment in patients with coagulation disorders, including the use of anticoagulants. Also in cases with high risk of scarring defects, such as in diabetic patients, older adults and those where surgery or scarring could generate functional alterations. An additional benefit of this technique is the conservation of the integrity of the skin, important in the clinical recognition of recurrences.

The main objective of the use of HeberPAG ${ }^{\circledR}$ in periocular BCCs is the preservation of the eye and the structures that surround it, as well as the conservation of vision, avoiding reconstructive surgery and obtaining a satisfactory cosmetic effect.

Although the impact of the results of HeberPAG ${ }^{\circledR}$ treatment promise to make it a new and powerful therapeutic option for non-melanoma skin cancer, the behavior and long-term follow-up of this series will be published in future articles, and will provide evidence-based information to demonstrate the stability and sustainability of the clinical response obtained in the periocular region. The inclusion of more representative sample sizes in future research will be taken into account.

\section{Conclusions}

The results of this study suggest that the use of $\mathrm{He}$ berPAG ${ }^{\circledR}$ could be considered as a useful and safe alternative as a conservative treatment in patients with periocular BCC when other therapies are not possible. 


\section{Ethical disclosures}

Protection of human and animal subjects. The authors declare that the procedures followed were in accordance with the regulations of the relevant clinical research ethics committee and with those of the Code of Ethics of the World Medical Association (Declaration of Helsinki).

Confidentiality of data. The authors declare that they have followed the protocols of their work center on the publication of patient data.

Right to privacy and informed consent. The authors have obtained the written informed consent of the patients or subjects mentioned in the article. The corresponding author is in possession of this document.

\section{Funding}

Center for Genetic Engineering and Biotechnology (CIGB), Havana. Ministry of Public Health of Cuba (MINSAP).

\section{Conflict of interest}

The authors declare no conflicts of interest.

\section{References}

1. Lewin JM, Carucci JA. Advances in the management of basal cell carcinoma. F1000Prime Rep. 2015;7:53.

2. Karimkhani C, Boyers LN, Dellavalle RP, Weinstock MA. It's time for 'keratinocyte carcinoma' to replace the term 'nonmelanoma skin cancer'. J Am Acad Dermatol. 2015;72:186-7.

3. Mohan SV, Chang AL. Advanced Basal Cell Carcinoma: Epidemiology and Therapeutic Innovations. Curr Dermatol Rep. 2014;3:40-5.

4. Baxter JM, Patel AN, Varma S. Facial basal cell carcinoma. BMJ. 2012; 345:e5342.

5. García Martín E, Fernández Tirado FJ. Periocular basal cell carcinoma treatment tendencies. Arch Soc Esp Oftalmol. 2010;85:261-2.

6. Wang $\mathrm{CJ}$, Zhang HN, Wu H. Clinicopathologic features and prognostic factors of malignant eyelid tumors. Int J Ophthalmol. 2013;6(4):442-7.

7. Kale SM, Patil SB, Khare N. Clinicopathological analysis of eyelid malignancies A review of 85 cases. Indian J Plast Surg. 2012;45(1):22-8

8. Marzuka AG, Book SE. Basal Cell Carcinoma: Pathogenesis, Epidemiology, Clinical Features, Diagnosis, Histopathology, and Management. Yale J Biol Med. 2015;88(2):167-79.

9. Gulleth Y, Goldberg N, Silverman RP, Gastman BR. What is the best surgical margin for a Basal cell carcinoma: a meta-analysis of the literature. Plast Reconstr Surg. 2010;126(4):1222-31.

10. Prokosch V, Thanos S, Spaniol K, Stupp T. Long-term outcome after treatment with $5 \%$ topical imiquimod cream in patients with basal cell carcinoma of the eyelids. Graefes Arch Clin Exp Ophthalmol. 2011;249:121-5.

11. Fantini F, Greco A, Del Giovane C, Cesinaro AM, Venturini M, Zane C., et al. Photodynamic therapy for basal cell carcinoma: clinical and pathological determinants of response. J Eur Acad Dermatol Venereol. 2011; 25(8):896-901.

12. Cosgarea R, Susan M, Crisan M, Senila S. Photodynamic therapy using topical 5-aminolaevulinic acid vs. surgery for basal cell carcinoma. J Eur Acad Dermatol Venereol. 2013;27(8):980-4.

13. Arits AH, Mosterd K, Essers BA, Spoorenberg E, Sommer A, De Rooij MJ, et al. Photodynamic therapy versus topical imiquimod versus topical fluorouracil for treatment of superficial basal-cell carcinoma: a single blind, non-inferiority, randomised controlled trial. Lancet Oncol. 2013;14(7):647-54.

14. Smith V, Walton S. Treatment of facial basal cell carcinoma: A review. Hindawi Publishing Corporation. J Skin Can. 2011;2011:380371.

15. Lasudry J. Management of eyelid tumors: general considerations. J Fr Ophtalmol. 2011;34(10):741-54.
16. Good LM, Miller MD, High WA. Intralesional agents in the management of cutaneous malignancy: a review. J Am Acad Dermatol. 2011; 64(2): 413-22.

17. Garcia-Vega $Y$, Anasagasti-Angulo L, Valenzuela-Silva $C$, Navarro-Mestre M Maribeth-Ordoñez S, Acosta-Medina D, et al. Retrospective Study of Periocular Non Melanoma Skin Cancer Treated with the Combination of IFN alpha2b and Gamma (HeberPAG ${ }^{\circledR}$ ). J Clin Exp Ophthalmol. 2015;6:478.

18. Jiménez Barbán Y, Vega Pupo C, Vila Pinillo D, Fernández Ychaso G, Arias Núñez V, Bello Rivero I. Uso de $\mathrm{HeberPAG}^{\circledR}$ en carcinoma basocelular periocular. Rev Cubana Oftalmol. 2014;27:3.

19. Bello-Rivero I, Garcia-Vega Y, Valenzuela-Silva C. Development of a new formulation of interferons (HEBERPAG ${ }^{\circledR}$ ) for BCC treatment. Cancer Res Ther. 2013;1(10):235-243.

20. Anasagasti Angulo L, Garcia Vega Y, Barcelona Perez S, Lopez Saura P, Bello Rivero I. Treatment of advanced, recurrent, resistant to previous treatments basal and squamous cell skin carcinomas with a synergistic formulation of interferons. Open, prospective study. BMC Cancer. 2009; 9:262-74.

21. García Vega Y, García García I, Collazo Caballero SE, Santely-Pravia EE, Cruz-Ramírez A, Tuero-Iglesias AD, et al. Pharmacokinetic and pharmacodynamic characterization of a new formulation containing synergistic proportions of interferons alpha- $2 \mathrm{~b}$ and gamma $\left(\mathrm{HeberPAG}^{\circledR}\right)$ in patients with mycosis fungoides: an open-label trial. BMC Pharmacol Toxicol. 2012;13:20.

22. Rene C. Oculoplastic aspects of ocular oncology. Eye. 2013;27:199-207.

23. Hayano SM, Whipple KM, Korn BS, Kikkawa DO. Principles of Periocular Reconstruction following Excision of Cutaneous Malignancy. J Skin Cancer. 2012;2012:438502.

24. Lewin JM, Carucci JA. Advances in the management of basal cell carcinoma. F1000Prime Rep. 2015;7:53.

25. Wu TP, Stein JA. Nonmelanoma skin cancer in young women- $J$ DrugsDermatol. 2013;12:568-72.

26. Göppner D, Leverkus M. Basal Cell Carcinoma: From the Molecular Understanding of the Pathogenesis to Targeted Therapy of Progressive Disease. J Skin Cancer. 2011;2011:650258.

27. Wehner MR, Shive ML, Chren MM, Han J, Qureshi AA, Linos E. Indoor tanning and non-melanoma skin cancer: systematic review and meta-analysis. BMJ. 2012;345:e5909.

28. Ferrucci LM, Cartmel B, Molinaro AM, Leffell DJ, Bale AE, Mayne ST. Indoor tanning and risk of early-onset basal cell carcinoma. J Am Acad Dermatol. 2012;67(4):552-62.

29. Robinson SN, Zens MS, Perry AE, Spencer SK, Duell EJ, Karagas MR. Photosensitizing agents and the risk of non-melanoma skin cancer: a population-based case-control study. J Invest Dermatol. 2013; 133(8):1950-5.

30. Stern RS. PUVA Follow-Up Study. The risk of squamous cell and basal cell cancer associated with psoralen and ultraviolet $A$ therapy: a 30-year prospective study. J Am Acad Dermatol. 2012;66(4):553-62.

31. Danial C, Lingala B, Balise R, Oro AE, Reddy S, Colevas A, et al. Markedly improved overall survival in 10 consecutive patients with metastatic basal cell carcinoma. Br J Dermatol. 2013;169:673-6.

32. Von Hoff DD, LoRusso PM, Rudin CM, Reddy JC, Yauch RL, et al. Inhibition of the hedgehog pathway in advanced basal-cell carcinoma. $\mathrm{N}$ Engl J Med. 2009;361: 1164-72.

33. Sekulic A, Migden MR, Oro AE, Dirix L, Lewis KD, Hainsworth JD, et al. Efficacy and safety of vismodegib in advanced basal-cell carcinoma. N Engl J Med. 2012;366:2171-9.

34. Chang AL, Solomon JA, Hainsworth JD, Goldberg L, McKenna E, Day BM, et al. Expanded access study of patients with advanced basal cell carcinoma treated with the Hedgehog pathway inhibitor, vismodegib. J Am Acad Dermatol. 2014;70(1):60-9.

35. Bello C, Vazquez-Blomquist D, Miranda J, Garcia Y, Novoa LI, Palenzuela D, et al. Regulation by IFN- $\alpha /$ IFN- $\gamma$ Co-Formulation (Herber$\mathrm{PAG}^{\circledR}$ ) of Genes Involved in Interferon-STAT-Pathways and Apoptosis in U87MG. Curr Top Med Chem. 2014;14(3):351-8.

36. Garcia Vega $Y$, Salva Camaño S, García Iglesias E, Cubero-Rego D, González-Gonzalez J, Bello-Rivero I. CIGB-128, as compassionate intracranial treatment in patients with non-operable or progressive high grade gliomas. J Cancer Res Ther. 2015;3(11):136-43.

37. Smeets NW, Kuijpers DI, Nelemans P, Ostertag JU, Verhaegh ME, et al. Mohs' micrographic surgery for treatment of basal cell carcinoma of the face-results of a retrospective study and review of the literature. $\mathrm{Br} \mathrm{J}$ Dermatol. 2004;151:141-7.

38. Takamori S, Kong K, Varma S, Leach I, Williams HC, Notingher I. Optimization of multimodal spectral imaging for assessment of resection margins during Mohs micrographic surgery for basal cell carcinoma. Biomed Opt Express. 2015;6:98-111.

39. Chren MM, Linos E, Torres JS, Stuart SE, Parvataneni R, Boscardin WJ. Tumor recurrence 5 years after treatment of cutaneous basal cell carcinoma and squamous cell carcinoma. J Invest Dermatol. 2013; 133(5):1188-96. 